\title{
The Curriculum of Tahfidz Al-Qur'an at The Mustawa Awwal of Pesantren Darul Quran Al-Karim, Baturraden, Central Java
}

\author{
Suwito $^{1}$, Ahmad Sahnan ${ }^{2}$, Safrudin Aziz ${ }^{3}$, Abdal Chaqil Harimi ${ }^{4}$, Maulana Mualim ${ }^{5}$ \\ \{suwitons@iainpurwokerto.ac.id ${ }^{1}$, sahnan@iainpurwokerto.ac.id ${ }^{2}$, \\ azeez@iainpurwokerto.ac.id ${ }^{3}$, abdal@iainpurwokerto.ac.id ${ }^{4}$, \\ maulanamualim@iainpurwokerto.ac.id $\left.{ }^{5}\right\}$
}

Faculty of Tarbiyah and Teacher Training Institut Agama Islam Negeri (IAIN) Purwokerto, Indonesia ${ }^{1,2,3,4,5}$.

\begin{abstract}
This article aims to describe, study, and analyze the curriculum of MustawaAwwal at PesantrenDarul Quran Al-Karim Baturraden, Central Java. MustawaAwal is an alternative educational institution applying non-formal education pathway which develops a unique curriculum by combining activities that focus on memorizing the Qur'an and achieving good UN (National Exam) scores. The study was conducted by direct observation, interviews, and documentation. The findings of this study indicate that the educational curriculum of MustawaAwwal comprises a target of memorizing $30 \mathrm{Juz}$ within 3 years of SMP/MTs duration and a target of average UN score of 8 . The implementation of the program shows that students are able to memorize 30 juz in the average duration of 2 years and 9 months while the average UN score achieved by them is 6.8 .
\end{abstract}

Keywords. MustawaAwwal, Darul Quran Al-Karim Karangtengah, Curriculum, Tahfidz Al-Quran

\section{Introduction}

The world of education in Indonesia is increasingly open to the quite varied needs and demands of the society so that it does not have to be referred to the formal education system conceptualized by the government.[1] One of the needs of the Indonesian society in this millennial era is Islamic education like the ones practiced in Pesantrens. Nowadays, Pesantrens are establised with the characteristics, i.e. expertice in certain fields in accordance with the expectations of the surrounding community.[2], [3]PesantrenDarul Quran Al-Karim Karangtengah, Baturraden, Central Java was established with the the learning objectives of being Hafidz or Hafidzah (Qur'an memorizing) within 3 years of learning, but still able to catch up with the materials of formal education. In that regard, it is very interesting to look at the curriculum of PesantrenDarul Quran Al-Karim where the learning objectives can be achieved well so far. Also, this study is interesting considering the high number of Muslims in Indonesia, but not many of them are able to read their own scriptures. 


\section{Non Formal Education and Curriculum}

Curriculum is the soul education,[4]-[7]the ones practiced in Pesantrens are not excluded.[3], [8]There are two categories of pesantren related to the curriculum they adopt, namely Pesantrens with formal and non formal education. The existence of non-formal education system in Indonesia is due to the demands of the surrounding community who expect their children to graduate with special expertise. In Law number 20 on the National Education System in 2003, it is written that "non-formal education is defined as education implemented outside the formal education institution and carried out with structures and levels." This means, that non-formal education needs to have a clear pattern and domain of continuation in directing the young generation of the Indonesian people. To create patterns and continuation in learning, a systematic curriculum in non-formal education is needed. Although the pattern is slightly different from the formal education, non-formal education must have a clear frame of reference to achieve its learning objectives. Therefore, the learning activity in non-formal education can be done with a series of conceptualized systems with material levels according to the ability of students to direct them to have the desired skills.[9]-[12]

To form a structured and tiered teaching, a curriculum is needed as a basis. Curriculum is the soul of teaching. Curriculum as an important part of education planning sets the teaching contents and materials so that it is able to navigate the implementation of teaching and learning activities. The curriculum of non-formal education is compiled differently from that of formal education (the national curriculum) and is designed based on the ideal concept of teaching outcomes to be achieved. Besides that, the curriculum non-formal education is directed at the target to make students knowledgeable and skillful in certain expertise, implemented with different learning techniques, and special material by teachers who are experts in their very own field. Curriculum is an essential guideline of teaching navigating and directing an educational institution in conducting the teaching-learning process in order to achieve maximum results. [8]

The curriculum in non-formal education could be formed based on the vision and mission of the education services providers in accordance with the ideology of the user community (stakeholders), provided that it does not go away from the concepts and ideas of national education.[13]KholisThohir (2017)[14] stated that "the development of pesantren curriculum basically cannot be separated from the vision of national development that seeks to save and improve national life." This means, that non-formal education are to consider the curriculum designed by the government as an important part that cannot be taken for granted, cannon be eliminated.[15]

In compiling a curriculum, the important thing to consider is the analysis of community needs, subjects of the classes, learning objectives, materials, strategies, and learning outcomes. All elements are integrated as a plan that will be carried out intensively and regularly in accordance with the levels of learning.

\section{The Curriculum of Mustawa Awaal and Its Implementation}

\subsection{History of Its Development}

MustawaAwwal is an educational institution at the level of Junior High School (SMP or MTs). This institution is under the auspices of the Center for Community Learning Activities (PKBM) Darul Quran Al-Karim, founded and managed by Darul Quran Al-Karim Foundation, Karangtengah, Baturraden, Banyumas, Central Java. Located Precisely on Barurraden Street (West Line), Karangtengah Village, Baturraden. 
MustawaAwwal was founded on April 1, 2015 by KH. SofwanMabrur, Dr. Muhammad Targhib, Sony Sumarsono, Dr. Suwito NS, Dr. AlizarIsna, RahminiHadi, Susilo, Ahmad Khozin, Kmomarudin, and SyafruddinAzis, S.IP.

The establishment of this institution was grounded by the concern of the initiators that the current educational conditions have not yet produced ideal persons, those who properly master and memorize the Qur'an, as the main source of Islam and properly master other fields of knowledge and science taught at the SMP/MTs level. This aspiration is set in the pattern of teaching (curriculum) with the objectives of graduating students who are not only able to memorize the Qur'an but also are able to practice the teachings of teh Qur'an with knowledge that they master.

In the process of its establishment, this institution decided to take the path of Non-Formal Education because of various reasons including the reasons for being more flexible in designing and implementing the curriculum. Learning from the experience of the available educational institutions, the target of 30 juz at the secondary level which takes only 3 years is a great challenge. According to a survey conducted by the curriculum development team before deciding the education style of MustawaAwwal, the target of $30 \mathrm{juz}$ at the junior high level would be very tough if going through formal channels (formal education). Therefore, the NonFormal Education style is taken.

Since its establishment in 2016, MustawaAwwal has actively operated for 4 years and has yielded alumni. The institution which has a vision of "Excellence in Qur'an Education, in realising Independent, Skillful, and Noble Mannered students" pledged itself as an institution that adheres to the theological system of Ahlussunnahwa Al-Jamaah with refering its religious practices to the Nahdhiyyahgoup.

As for the students development since its establishment in 2016 and for the rest of the operation, this institution accommodates students who are truly interested in alternative education that is completely different from schools in general. The target of student admission in the first year (2016) was 13 male students. There were 21 applicants participated in the selection process. The quota-interest ratio at that time was 1: 1.61 which was a good yet pleasing beginning. The quota of the second year (2017) admission was increased by accepting 25 students both male and female students. There were 39 participants who registered and participated in the selection. The second year the quota ratio was received with an interest of 1: 1.56. In the third year (2018), MustawaAwwal increased its capacity by fixing a quota of 30 students. The number of prospective students who registered was 42 or the quota ratio of 1: 1.4. As for the year 2019, the quota is still 30 students with interest of 43 or a ratio of 1: 1.43.

In terms of age, MustawaAwwal is a newly born institution. However, this institution has been known nationally by prospective trustees (parents). The farest students came from Batam and the province of West Java, precisely some of the students came from Ciamis (West Java). The distribution of the students' origin is those coming from Banyumas (Central Java), Kebumen (Central Java), Pemalang (Central Java), Cilacap (Central Java), Purbalingga (Central Java), Ciamis (West Java), and Batam (Riau Islands). There are however still weaknesses related to the student admission in MustawaAwwal, one of which is not yet able to accommodate more students coming from the village where this institution is located because of the admission requirements that cannot be fulfilled by them, namely students must have memorized at least 1 juz (JuzAmma). Because of this requirement, some of them were refused to enter MustawaAwwal's flagship program, which is memorizing $30 \mathrm{Juz}$ at the level of SMP/MTs. 


\subsection{Mustawa Awwal Curriculum}

Curriculum is structured based on a) the ideals of the institution and its founders, b) the needs of the community, and c) the interests and needs of national development. The founders of MustawaAwwal have the ideal that children who graduate from junior high school or equivalent must be able to read their respective scriptures. Because the context is of Islam, Muslim children must be able to read the Qur'an. However, the reality does not say so. The proof is, according to a survey conducted by Ma'had IAIN Purwokerto, only $26.5 \%$ applicants to IAIN Purwokerto (graduates of high school SMA/MA/SMK) passed the exmination of BTA (Qur'an reading and Writing) and PPI (Worship Knowledge and Practice). Meaning that, this also happens to elementary and junior high school graduates of Muslim children, more than $40 \%$ of them have not been able to read the Qur'an. This fact is considered very alarming for muslim parents. According to the ideals of its founders, the curriculum of MustawaAwwal is an alternative curriculum that is different from schools in general. This is because, it has been proven that the national education institution clearly has not fully contributed to the success of students in their lives. Even the content is arguably a failure. The content of lessons learned in elementary / junior high schools has not shown significance in the praxis level. Including English in middle school and Arabic in High School. Almost all SMP/MTs fail to teach English because it is proven that SMP/MTs graduates cannot communicate using the language. The question is, what is the success of the formal school?

Because of that basis, MustawaAwwal did a unique curriculum design called "Alternative Curriculum Plus". It is a curriculum whose outputs and learning outcomes are focused on memorization of the Qur'an and the teaching of Islamic religioun with additional material "plus" the materials for National Examination (UN).

The Competencies in MustawaAwwal consist of Package Core Competencies (KIP) and Additional Core Competencies (KIT). The package core competency is the curriculum package established by PermenDikbud Number 20 Year 2016 about Competency Standard of Graduates. While the Additional Core Competencies (KIT) are the core competencies added by the Darul Quran Al-Karim Foundation in accordance with the Darul Qur'an Al-Karim Foundation Decree Number 31 Year 2015 regarding the Additional Core Competencies (KIT) of the DarulQural Al-Karim Foundation. The KIT is as follows: Able to show memorization of 30 juz to the cleric, caregivers, and peers through "deposit" (gradual memorization) and tasmi' activities (memorization listening program). Understanding the concepts of Tafhimand Tarqiq. Understanding Gharib readings (isymam, imalah, etc.). Able to correct peer's reading related to reading tafhim and tarqiq. Able to correct peer's reading related to Gharib reading. Having the habit of taking ritual ablution (wudhu) before holding a mushaf(holy book). Having the habit of praying qabladaras (prayer before learning/reciting the Qur'an). Being accustomed to tadarrus while waiting for iqamah. Having discipline in carrying out various activities inside Pesantren, including tahsin and tahfidz. Being accustomed to do honest behavior in the learning process of tahsin and tahfidz. Having empathy for peers who experience difficulties learning related to tahsin and tahfidz. Having an attitude of respect for teachers and friends in the learning activities. Having a polite attitude to all people who live in the Pesantren and to the guests.

The materials taught are those referred to the Package B Equalization Program, namely Islamic Religion, PPKN (Citizenship), Indonesian Language, Mathematics, Natural Sciences, Social Sciences, Javanese Language, and Physical Education. The subjects rgerding as KIT are Tahsin and Tahfidz Al-Quran. The teacher qualification standards in MustawaAwwal are divided into 2 criteria. For teachers to achieve KIP are those with S1 (BA) qualification of their fields and memorized 30 Juz of Quran in a mutqin manner and to have sanad.

The Learning and tahfidz process from Monday to Thursday is carried out in 3 patterns, namely 1) class guided by Ustadz, 2) peer teaching with santri fellow, and 4) learning independently. The learning process is carried out by reversing the hours of learning, studying 
Qur'an from the morning till noon and studying the UN materials in the afternoon to evening. In detail, the learning activities are carried out as follows; starting at 03.30 the day is begun with Tahajjud prayer and murajaah until 04.30. After Subh (dawn) i.e. 05.00-06.00 memorization "deposit" to the caregivers/ustdaz. Afterwards, at 07.00-10.30, memorizing new verses and at the same time checking the yesterday's memorization in a class guided by a teacher. From 13.00 to 15.00 students continue the memorization independently in groups. At this time, students memorize Qur'an with their peers. UN materials are taught on the sidelines of learning Qur'an. As for Friday and Saturday, the learning activity is started from 07.00 till 15.00 , it is done by studying UN materials with Qur'an recitation in the sidelines.

The facilities used in the learning process in general are similar to those used in other learning processes. The important thing in the process of tahfidz Quran is to use standard Medina Mushaf(Qur'an) or use other Qur'an consistently. In addition, students are advised to have a flash disk and active speakers to play the memorization recordings of the verses that they have memorized, this is done during the resting times.

The assessment of tahfidz is carried out with memorization "deposit" (gradual memorization) to the Haed of Pesantren (Kyai). However, before doing so, one must "deposit" the verses to his peers (santri fellow), and then "deposit" them to ustadz. There are regular weekly exams by applying weekly tasmi' (memorization listening). In addition, there are semesterly and yearly tasmi'.

\section{Closing}

There are two core competencies in the curriculum of MustawaAwwal, the Center for Community Learning Activities (PKBM) Darul Quran Al-Karim, namely a) KIP (Package Core Competencies), and b) KIT (Additional Core Competencies) by the Foundation. The material structure that was developed subsquently includes UN material derivatives (Islamic religion, Citizenship, Indonesian Language, Mathematics, Natural Sciences, Social Sciences, and Physical Education), while KIT material derivatives were Quran Tahsin, Quran Tahfidz, Arabic and English. In 2019, students who graduated with 30 juz memorization is $81.81 \%$, and the average UN score was 67 with the highest average score of 94.

\section{References}

[1] B. M. Ormond, "Curriculum decisions-the challenges of teacher autonomy over knowledge selection for history," J. Curric. Stud., vol. 49, no. 5, pp. 599-619, 2017.

[2] M. Hasan, "Inovasi dan Modernisasi Pendidikan Pondok Pesantren," KARSA J. Soc. Islam. Cult., vol. 23, no. 2, pp. 296-306, 2015.

[3] N. Husna and Z. Arifin, "Curriculum Development of Madrasah Tahfidz-Based Pesantren," Ta'dib J. Islam. Educ. (Jurnal Pendidik. Islam., vol. 21, no. 2, pp. 125-136, 2016.

[4] J. Sebba, R. Byers, and R. Rose, Redefining the whole curriculum for pupils with learning difficulties. Routledge, 2018.

[5] M. A. Alsubaie, "Hidden curriculum as one of current issue of curriculum.," J. Educ. Pract., vol. 6, no. 33, pp. 125-128, 2015.

[6] H. A. Alismail and P. McGuire, "21st Century Standards and Curriculum: Current Research and Practice.," J. Educ. Pract., vol. 6, no. 6, pp. 150-154, 2015.

[7] H. Widyastono, "Kurikulum Tingkat Satuan Pendidikan Kajian Yuridis dan Konseptual," J. Pendidik. dan Kebud., vol. 13, no. 66, pp. 325-339, 2016. 
[8] M. Muhlisin, "Pondok Pesantren Based: Madrasah Curriculum Development at MA Al-Ishlah Sendangagung Paciran Lamongan Jawa Timur," HIKMATUNA J. Integr. Islam. Stud., vol. 5, no. 1, pp. 15-28, 2019.

[9] C. R. Prihantoro, "The perspective of curriculum in Indonesia on environmental education," Int. J. Res. Stud. Educ., vol. 4, no. 1, pp. 77-83, 2015.

[10] M. Amri, S. Tahir, and S. Ahmad, "The Implementation of Islamic Teaching in Multiculturalism Society: A Case Study at Pesantren Schools in Indonesia," Asian Soc. Sci., vol. 13, no. 6, p. 125, 2017.

[11] S. Ma'arif, "Education as a Foundation of Humanity: Learning from the Pedagogy of Pesantren in Indonesia," J. Soc. Stud. Educ. Res., vol. 9, no. 2, pp. 104-123, 2018.

[12] H. Indra, "Salafiyah Curriculum At Islamic Boarding School in The Globalization Era," Tarbiya J. Educ. Muslim Soc., vol. 4, no. 1, pp. 74-88, 2017.

[13] I. Rosmilawati, "Jalan Panjang Menuju Sekolah Alternatif: Refleksi Pengalaman Remaja Kurang Beruntung Dalam Meraih Pendidikan,” J. Eksistensi Pendidik. Luar Sekol., vol. 2, no. 1, 2018.

[14] K. Tohir, "Kurikulum Dan Sistem Pembelajaran Pondok Pesantren Salafi Di Kecamatan Kresek Kabupaten Tangerang Provinsi Banten,” J. Anal. Islam., vol. 6, no. 1, pp. 11-20, 2017.

[15] Y. W. Dasor, V. Sumardi, and R. Hudin, "Dinamika Politik Lokal Dalam Penerapan Kebijakan Desentralisasi Pendidikan Di Kabupaten ManggaraI," Eksplor. BUDAYA DAN Masy. DALAM Pendidik., p. 444. 